\title{
Hemşirelik Öğrencilerinin Meslek Seçimini Etkileyen Faktörler
}

\author{
Sevil Olğun®®, Derya Adıbelli®
}

${ }^{1}$ Adnan Menderes Üniversitesi, Hemşirelik Fakültesi, Aydın, Türkiye ${ }^{2}$ Akdeniz Üniversitesi Kumluca Sağlık Bilimleri Fakültesi, Hemşirelik Bölümü, Antalya, Türkiye

Sevil Olğun, Dr. Öğr. Üyesi Derya Adıbelli, Dr. Öğr. Üyesi

Iletişim:

Dr. Öğr. Üyesi Derya Adıbelli

Akdeniz Üniversitesi Kumluca Sağlık Bilimleri Fakültesi, Hemşirelik Bölümü, Antalya, Türkiye Tel: +90 2428870910

E-Posta: aricanderya@gmail.com

Gönderilme Tarihi : 18 Temmuz 2018

Revizyon Tarihi : 18 Temmuz 2018

Kabul Tarihi : 18 Aralık 2018
ÖZET

Amaç: Bu araştırma, hemşirelik öğrencilerinin meslek seçimini etkileyen faktörleri belirlemek amacıyla yapılmıştır.

Yöntem: Araştırma 1-30 Mayıs 2016 tarihleri arasında yapılmıştır. Araştırmanın evrenini bir Sağlık Yüksekokulu'nda öğrenim gören 750 öğrenci, örneklemini ise çalışmaya katılmayı kabul eden 501 öğrenci oluşturmuştur. Verilerin toplanmasında araştırmacılar tarafından hazırlanan tanıtıı özellikler formu ve Hemşirelikte Meslek Seçimi Ölçeği (HMSÖ) kullanıImıştır. Verilerin değerlendirilmesinde SPSS 20,0 programı kullanılmış, analizinde ortalama, yüzdelik, bağımsız gruplar t testi uygulanmıştır.

Bulgular: Öğrencilerin yaş ortalaması $20,82 \pm 1,68, \% 66,9^{\prime}$ u kızdır. Hemşirelik mesleğini $\% 65,7^{\prime}$ 'si isteyerek seçtiğini ve $\% 52,3^{\prime}$ ü ilk tercihi olduğunu belirtmiştir. Öğrencilerin çoğunun $(\% 74,3)$ bölümünden memnun oldukları, hemşirelik mesleğini benimsedikleri $(\% 77,6)$ ve bölümünü değiştirmek istemedikleri $(\% 67,3)$ belirlenmiştir. Öğrencilerin bölüm değiştirme istekleri ve mesleği benimseme durumları ile Hemşirelikte Meslek Seçimi Ölçeği alt boyutu olan Mesleki Uygunluk puanı arasındaki fark anlamlı olarak bulunurken $(p=.000)$; ilgili değişkenler ile Yaşamsal Nedenler alt boyutu puan ortalamaları arasında anlamlı bir fark bulunmamıştır $(p>0,05)$. Ölçek maddelerinin cinsiyete göre dağılımı incelendiğinde; her iki cinsiyette de meslek seçiminde etkili olan ilk üç ifade sırasılla "Her zaman insanlara yardım etmek istemişimdir $(\% 36,4)$ ", "Çevremdeki insanlar iyi bir hemşire olacağımı söylerler $(\% 30,2)$ " ve “Hemşirelikte işsiz kalınmayacağını düşünüyorum $(\% 26,2)$ " olarak belirlenmiştir.

Sonuç: Araştırma bulgularından, öğrencilerin hemşirelik mesleğini benimsedikleri ve kendilerine uygun buldukları söylenebilir. Anahtar sözcükler: Hemşirelik, öğrenci, meslek seçimi

\section{FACTORS AFFECTING/INFLUENCING CAREER CHOICES OF NURSING STUDENTS}

\section{ABSTRACT}

Purpose: This research has been done with the aim of determining (to determine the) the factors that affect the choice of profession of nursing students.

Methods: The research has been done between the dates of 1-30 May 2016. The target population of the research is 750 students who study in a High School of Health and participants of the research are 501 students who accept participating in the study. In data collection, a form of introductive characteristics prepared by researchers and Scale of Choice of Profession in Nursing (SCPN) have been used. In data evaluation, SPSS 20.0 program has been used and average, percentage, independent samples t-test have been implemented.

Results: The average age of the students is $20.82 \pm 1.68,66.9 \%$ of them are female. $65.7 \%$ of them have stated that they have chosen the profession of nursing intentionally and $52.3 \%$ of them have stated that nursing has been their first choice. While there is a significant difference between the point of Professional Conformity which is a sub-dimension of the Scale of Choice of Profession in Nursing and the desire of changing the department of the students and the situation of profession adoption $(p=.000)$, any significant difference hasn't been found between related variables and point averages of Vital Reasons subdimension ( $p>0.05$ ). When the distribution of scale items according to the gender is examined, the first three statements which are effective in choice of profession for both genders are "I always want to help people (\% 36.4)", "People around me say that I will be a good nurse (\% 30.2)" and "I think that If you are a nurse, you can't be unemployed (\% 26.2)".

Conclusion: It can be stated according to the research findings that students adopt the profession of nursing and they think that nursing is appropriate for them.

Keywords: Nursing, student, career choice 
M eslek; bireyin yaşamını sürdürmesi için yerine getirmesi gerekli, araştırma ve deney, uygulama süreci üzerine temellenmiş, yoğun bilgi birikimi, etik ilkeleri/kodları olan, görev, yetki ve sorumlulukları yasalarla belirlenmiş, otonom yapıya sahip, belirli bir parasal kazanç karşıı̆ı yapılan hizmettir (1). Meslek bireyin yaşamındaki en önemli seçimlerinden biridir. Kişinin tercih ettiği meslek, bireyin yaşantısına yön vererek kiminle evleneceğini, dünya görüşünü ve alışkanlıklarını etkilediği gibi (2), yaşam tarzını, gelirini, yaşayacağı çevreyi, ilişkide bulunacağı insanları belirlemesini de etkiler $(3,4)$. Yeni bir yaşam şekli, belli bir çalışma ortamı, farklı bir yeteneğin kullanılması ve geliştirilmesini gerektiren meslek seçimi, orta öğretimde okul yıllarında belirlenir (3). Yapılan bir çalışmada lise son sınıf öğrencilerinin meslek seçiminde etkili faktörlerin sırasıyla iş olanağının olması $(\% 67,4)$, ilgi ve yeteneklerine uygunluk (\%56), ekonomik getirinin yüksekliği $(\% 53,9)$, ailenin isteği ve baskısı $(\% 35,1)$, mesleğin statüsü $(\% 29,7)$, sosyal çevre $(\% 24,5)$, öğrenciye ve ailesine getireceği yük $(\% 17,7)$ ve medyanın etkisi $(\% 8,7)$ olarak bulunmuştur (2).

Hemşirelik öğrencilerinde meslek seçimi ile ilgili yapılan çalışmalara bakıldığında öğrencilerin çoğunluğunun hemşireliği isteyerek seçtiği, bölümlerinden memnun olduğu, hemşirelikte işsiz kalınmayacağı düşüncesi, insanlara yardım etme duygusu, iyi bir kariyer fırsatı sağlaması gibi faktörlerin meslek seçiminde etkili olduğu bulunmuştur (5-10).

Farklı ülkelerde yapılan çalışmalarda öğrencilerin hemşireliği seçmelerinin nedenleri; insanlara bakım hizmeti sağlama ve yardım etme isteği, istihdam olanağının olması, hemşireliği sevmeleri $(11,12)$, aile ve yakın çevrenin etkisi, toplumun ihtiyaç duyduğu bir meslek olması, sağlıkla ilgili bir alan olması, mesleği kendine uygun görme, maaşının yüksek olması (11), kabul koşullarının kolay olması, hastane ortamını sevme şeklindedir (13).

Hemşirelik öğrencilerinin meslek yaşamında mesleğin gerektirdiği profesyonelliği uygulayabilmesi ve kaliteli sağlık hizmeti sunabilmesi için mesleği tanıyıp, severek ve bilinçli olarak seçmesinin önemli olduğu belirtilmektedir (8). Topluma ve bireye yönelik çok yönlü sorumluluğu ve rolü olan hemşirelik mesleğinin uygulamaları, insanı doğumundan ölümüne kadar geçen süre içinde, sağlık ve hastalıktaki konumu ile anlamaya temellendirilmiştir (14). Bu nedenle hemşirelik gibi insan yaşamını doğrudan etkileyen bir mesleğin bilinçli seçilmesi gereklidir. Bilinçli olarak yapılan meslek seçimi kişinin meslekteki başarısını ve iş doyumunu doğrudan etkilediği için hemşirelikte de meslek seçiminin nedenlerinin irdelenmesi gerekmektedir. Bu çalışma hemşirelik öğrencilerinin meslek seçiminde etkili olan faktörleri belirmek amacıyla yapılmıştır.

\section{Yöntem}

Araştırmanın evren ve örneklemi

Araştırma 1-30 Mayıs 2016 tarihleri arasında bir Sağlık Yüksekokulu Hemşirelik Bölümü’nde öğrenim gören öğrencilerle yapılmıştır. Araştırmanın evrenini ilgili okulda öğrenim gören 750 öğrenci, örneklemini ise çalışmaya katılmayı kabul eden 501 öğrenci oluşturmuştur. SPSS 23.0 programında veri kümesinde 69 verinin kayıp olduğu ve yapılan kayıp veri analizinde bu verilerin random dağıldığı belirlenmiştir (EM Means Sig. değeri, $p>0,05$ ). Aynı programda yerine koyma işlemi (Replace Missing Values) ile kayıp veriler veri kümesine dâhil edilerek çalışma 501 öğrenci ile tamamlanmıştır.

\section{Verilerin toplanması}

Veriler, ders saatleri dışında sınıf ortamında öğrencilere anket formu dağıtılıp 15-20 dk'da doldurmaları istenerek geri toplanmıştır. Verilerin toplanmasında araştırmacılar tarafından hazırlanan tanıtıc özellikler formu ve Hemşirelikte Meslek Seçimi Ölçeği (HMSÖ) kullanılmıştır.

\section{Tanıtıcı özellikler formu}

Öğrencilerin yaş, cinsiyet, sınıf, medeni durum, anne ve babaların eğitim ve çalışma durumları, aile tipi ve ailenin gelir durumuna ilişkin sosyo-demografik 11 soru ve hemşirelik mesleğinin tercih etmeye ilişkin 8 soru olmak üzere toplam 19 sorudan oluşan bir formdur.

\section{Hemşirelikte Meslek Seçimi Ölçeği (HMSÖ)}

Zysberg ve Berry (15) tarafından geliştirilen ölçeğin Türkçe formunun geçerlik güvenirliği Önler ve Saraçoğlu (16) tarafından yapılmıştır. Ölçek, hemşirelik öğrencilerinin meslek seçimini etkileyen nedenleri belirlemek amacıyla geliştirilmiştir. Likert tipinde yanıtlanan ölçek 0-100 arası puanlanmaktadır. Mesleki uygunluk (MU) (Ölçek maddeleri; 1, 2, 3, 4, 5, 7, 9, 14, 15, 16, 17) ve Yaşamsal Nedenler (YN) (Ölçek maddeleri; 6, 8, 10, 11, 12, 13) alt boyutlarından oluşmaktadır. Toplam ölçek ve alt boyut puanları katıIımcıların ölçeğe verdikleri puanların toplamının ölçekteki soru sayısına bölünmesiyle elde edilmektedir. Ölçekten alınan puanlara göre bağımsız değişkenler ile hemşirelik mesleğini seçmelerini etkileyen nedenler karşılaştırılmaktadır. Yapılan çalışmalarda ölçeğin MU ve YN alt boyutlarının Cronbach's alfa değerleri sırasıyla 0,86 ve 0,78 (15), 0,85 ve 0,45 (7) olduğu bulunmuştur. Bu çalışmada ise, 
0,77 ve 0,61 olarak, ölçeğin genel Cronbach alfa değeri ise 0,80 olarak bulunmuştur.

Araştırma örnekleminin ( $n=501)$ gücünü belirlemek için çalışma sonrası yapılan PostHoc analizinde, örneklemin \%5 etki boyutu ile \%95 güven aralığında, \%99 güç" sağladığı bulunmuştur ( $G *$ Power 3.0.10).

\section{Verilerin değerlendirilmesi}

Veriler, SPSS 20,0 programında değerlendirilmiş ve verilerin analizinde tanımlayıcı istatistiklerin yanı sıra, sayısal değişkenler normal dağıldığından (Kolmogorov-Smirnov, $p>0,05)$ bağımsız gruplar t testi kullanılmıştır. Tip 1 hata düzeyinin \%5'in altında olduğu durumlar istatistiksel anlamlılık olarak değerlendirilmiştir.

\section{Etik ilkeler}

Araştırmanın yapılabilmesi için ilgili kurumdan yasal izin (Sayı: 74833469-900) alınmıştır. Uygulamadan önce öğrencilere bireysel olarak, çalışmanın amacı, anketi doldurma süresi, çalışmaya katılmanın gönüllük esasına dayandığı, katılımlarını herhangi bir noktada sonlandırabilecekleri, verdikleri bilgilerin araştırma dışında kullanılmayacağı, anketlere isim yazmanın gerekli olmadığı gibi açıklamalar yapılıp, varsa soruları yanıtlandıktan sonra çalışmaya katılımları konusunda sözel onamları alınmıştır. Ayrıca ölçeğin çalışmada kullanılabilmesi için ölçeği geliştiren ve Türkçe'ye uyarlayan araştırmacılardan izin alınmıştır.

\section{Araştırmanın sınırlılıkları}

Çalışmadan elde edilen bulgular, araştırmanın örneklemi ile sınırlıdır.

\section{Bulgular}

Öğrencilerin sosyo-demografik özellikleri incelendiğinde; yarıdan fazlasının kız öğrencilerden oluştuğu $(\% 66,9)$, tamamına yakınının çalışmadığı $(\% 90,4)$, yaklaşık yarısının annesinin $(\% 48,5)$ ve babasının $(\% 35,7)$ ilkokul düzeyinde eğitime sahip olduğu ve çoğunluğunun gideri dengeleyen bir gelire sahip olduğu $(\% 71,8)$ bulunmuştur (Tablo 1$)$.

Öğrencilerin okudukları bölüme ilişkin özellikleri incelendiğinde; yarıdan fazlasının hemşireliği ilk sırada $(\% 52,3)$ ve isteyerek $(\% 55,7)$ tercih ettiği bulunmuştur. Öğrencilerin çoğunluğu hemşirelik bölümünden memnun olmakla $(\% 74,3)$ birlikte, mesleği benimsediklerini $(\% 77,6)$ ve bölüm değiştirmeyi düşünmediklerini $(\% 63,3)$ belirtmişlerdir (Tablo 2).

Öğrencilerin hemşirelik bölümüne ilişkin düşünceleri ile HMSÖ alt boyut puan ortalamaları karşılaştırıldığında;
Tablo 1. Öğrencilerin sosyo-demografik özellikleri

\begin{tabular}{|c|c|c|}
\hline Sosyo-demografik Özellikler & Sayı & $\%$ \\
\hline $\begin{array}{l}\text { Cinsiyet } \\
\text { Kadın } \\
\text { Erkek }\end{array}$ & $\begin{array}{l}335 \\
166\end{array}$ & $\begin{array}{l}66,9 \\
33,1\end{array}$ \\
\hline $\begin{array}{l}\text { Sinıf } \\
\text { 1. Sinıf } \\
\text { 2. Sinıf } \\
\text { 3. Sinıf } \\
\text { 4. Sinıf }\end{array}$ & $\begin{array}{c}95 \\
186 \\
184 \\
36\end{array}$ & $\begin{array}{r}19,0 \\
37,1 \\
36,7 \\
7,2\end{array}$ \\
\hline $\begin{array}{l}\text { Çalışma durumu } \\
\text { Çalışmıyorum } \\
\text { Çalışıyorum }\end{array}$ & $\begin{array}{c}453 \\
48\end{array}$ & $\begin{array}{c}90,4 \\
9,6\end{array}$ \\
\hline $\begin{array}{l}\text { Anne Eğitim Düzeyi } \\
\text { Okur yazar değil } \\
\text { Okur yazar } \\
\text { Illkokul } \\
\text { Ortaokul } \\
\text { Lise } \\
\text { Üniversite ve üstü }\end{array}$ & $\begin{array}{c}58 \\
46 \\
243 \\
70 \\
62 \\
22\end{array}$ & $\begin{array}{c}11,6 \\
9,2 \\
48,5 \\
14,0 \\
12,4 \\
4,3\end{array}$ \\
\hline $\begin{array}{l}\text { Baba Eğitim Düzeyi } \\
\text { Okur yazar değil } \\
\text { Okur yazar } \\
\text { Illkokul } \\
\text { Ortaokul } \\
\text { Lise } \\
\text { Üniversite ve üstü }\end{array}$ & $\begin{array}{c}10 \\
31 \\
179 \\
10 \\
126 \\
53\end{array}$ & $\begin{array}{c}2,0 \\
6,2 \\
35,7 \\
20,4 \\
25,1 \\
10,6\end{array}$ \\
\hline $\begin{array}{l}\text { Ailenin Gelir Durumu } \\
\text { Gelir giderden az } \\
\text { Gelir gideri dengeler } \\
\text { Gelir giderden fazla }\end{array}$ & $\begin{array}{c}91 \\
360 \\
50\end{array}$ & $\begin{array}{l}18,2 \\
71,8 \\
10,0\end{array}$ \\
\hline
\end{tabular}

Tablo 2. Öğrencilerin okudukları bölüme ilişkin özellikleri

\begin{tabular}{lcc} 
Özellikler & Sayı & $\%$ \\
\hline Tercih sırası & & \\
1. & 262 & 52,3 \\
2. & 73 & 14,6 \\
3 ve üzeri & 166 & 33,1 \\
Hemşireliği isteyerek tercih etme & & \\
Evet & 329 & 55,7 \\
Hayır & 172 & 34,3 \\
$\begin{array}{l}\text { Bölümden memnuniyet durumu } \\
\text { Memnunum }\end{array}$ & \\
Memnun değilim & 372 & 74,3 \\
Mesleği benimseme durumu & 129 & 25,7 \\
Evet & & \\
Hayır & 389 & 77,6 \\
Bölüm değiştirmeyi düşünme durumu & 112 & 22,4 \\
Evet & & \\
Hayır & 184 & 36,7 \\
& 317 & 63,3
\end{tabular}

mesleği benimseme ve bölüm değiştirmeyi düşünme durumları ile $\mathrm{MU}$ alt boyutu puan ortalamaları arasında istatistiksel açıdan anlamlı fark bulunurken $(p<0,05)$; aynı değişkenler ile $\mathrm{YN}$ alt boyutu puan ortalamaları arasında anlamlı fark bulunmamıştır ( $p>0,05$ ) (Tablo 3 ). 
HMSÖ maddelerinin cinsiyete göre dağılımı Tablo 4'te verilmiştir. Tablo incelendiğinde her iki cinsiyette de meslek seçiminde etkili olan ilk üç maddenin "Her zaman insanlara yardım etmek istemişimdir (\%36,4)", "Çevremdeki insanlar iyi bir hemşire olacağımı söylerler $(\% 30,2)$ " ve "Kendimi ifade edebilmemi sağlayan bir iş yapmak istedim $(\% 27,6)$ " şeklinde olduğu tespit edilmiştir.

Tablo 3. Öğrencilerin okudukları bölüme ilişkin düşünceleri ile HMSÖ alt boyut puan ortalamalarının karşılaştıııması

\begin{tabular}{|c|c|c|}
\hline Düşünceler & MU & YN \\
\hline & $X \pm S S$ & $X \pm S S$ \\
\hline \multicolumn{3}{|l|}{ Mesleği benimseme } \\
\hline Benimsedim & $44,52 \pm 11,58$ & $18,52 \pm 6,35$ \\
\hline Benimsemedim & $29,35 \pm 11,57$ & $18,35 \pm 6,88$ \\
\hline Test ve Anlamlılık & $\begin{array}{c}t=12,174 \\
p=0,000\end{array}$ & $\begin{array}{l}t=0,264 \\
p=0,792\end{array}$ \\
\hline \multicolumn{3}{|c|}{ Bölüm değiștirmeyi düşünme } \\
\hline Düşünüyorum & $35,11 \pm 12,70$ & $18,53 \pm 6,94$ \\
\hline Düşünmüyorum & $44,70 \pm 12,23$ & $18,41 \pm 6,17$ \\
\hline Test ve Anlamlılık & $\begin{array}{l}t=-8,288 \\
p=0,000\end{array}$ & $\begin{array}{l}t=0,269 \\
p=0,788\end{array}$ \\
\hline
\end{tabular}

\section{Tartışma}

Hemşirelik öğrencilerinin meslek seçimini etkileyen faktörleri belirlemek amacıyla tanımlayıcı tipte yapılan çalışmada katılımcıların yarıdan fazlasının kız öğrenci olduğu ve tamamına yakınının çalışmadığı bulunmuştur. Öğrencilerin yaklaşık yarısının annesi ve babası ilkokul mezunudur. Araştırma bulgumuzu destekleyen çalışmalar bulunmakla birlikte $(6,17)$, bazı çalışmalarda anne ve babası ilkokul mezunu olan öğrencilerin oranı daha yüksek bulunmuştur $(5,18)$. Çalışmamızda öğrencilerin çoğunluğunun ailesinin geliri giderine denktir. Bir çalışmada benzer sonuç tespit edilmişken (8); farklı bir çalışmada öğrencilerin ailelerinin yarıya yakınının aylık gelirinin asgari ücret düzeyinde olduğu belirtilmiştir (19).

Öğrencilerin okudukları bölüme ilişkin görüşleri incelendiğinde; yarıdan fazlasının hemşirelik bölümünü ilk sırada tercih ettikleri saptanmıştır. Çalışmamıza benzer olarak, Ince ve Khorshid'in çalışmasında da öğrencilerin yarıdan fazlasının hemşireliği ilk sırada tercih ettikleri belirlenmiştir (7). Çınar ve ark.'nın çalışmasında öğrencilerin $\% 55,1^{1}$ inin ilk 5 tercihleri arasında (18), Çıtak Tunç ve ark.'nın çalışmasında

Tablo 4. HMSÖ maddelerinin meslek seçimi üzerindeki etkisinin cinsiyete göre dağllımı (ntoplam=501, nkadın=335, nerkek=166)

\begin{tabular}{|c|c|c|c|c|c|c|c|c|c|c|c|c|}
\hline \multirow[t]{3}{*}{ Ölçek Maddeleri } & \multicolumn{6}{|c|}{ Etkili Oldu } & \multicolumn{6}{|c|}{ Etkili Olmadı } \\
\hline & \multicolumn{2}{|c|}{ Kadın } & \multicolumn{2}{|c|}{ Erkek } & \multicolumn{2}{|c|}{ Toplam } & \multicolumn{2}{|c|}{ Kadın } & \multicolumn{2}{|c|}{ Erkek } & \multicolumn{2}{|c|}{ Toplam } \\
\hline & Sayı & $\%$ & Sayı & $\%$ & Sayı & $\%$ & Sayı & $\%$ & Sayı & $\%$ & Sayı & $\%$ \\
\hline Her zaman hemşire olmak istemişimdir & 30 & 9,1 & 9 & 5,4 & 39 & 7,8 & 51 & 15,4 & 49 & 29,5 & 100 & 20,1 \\
\hline Hemşireliğin kişiliğime uygun bir iş olduğunu düşünüyorum & 1 & 0,3 & 0 & 0 & 1 & 0,2 & 12 & 3,6 & 19 & 11,4 & 31 & 6,2 \\
\hline Her zaman insanlara yardım etmek istemişimdir & 119 & 36,0 & 62 & 37,3 & 181 & 36,4 & 5 & 1,5 & 1 & 0,6 & 6 & 1,2 \\
\hline Kendimi ifade edebilmemi sağlayan bir iş yapmak istedim & 102 & 30,8 & 35 & 21,1 & 137 & 27,6 & 5 & 1,5 & 6 & 3,6 & 11 & 2,2 \\
\hline Hemşireliğin benim için iyi bir kariyer fırsatı olduğunu düşünüyorum & 55 & 16,6 & 13 & 7,8 & 68 & 13,7 & 18 & 5,4 & 20 & 12,0 & 38 & 7,6 \\
\hline Başka bir iş yapmak isterdim ama yapamadım & 60 & 18,1 & 45 & 27,1 & 105 & 21,1 & 47 & 14,2 & 18 & 10,8 & 65 & 13,1 \\
\hline Çevremdeki insanlar iyi bir hemşire olacağımı söylerler & 122 & 36,9 & 28 & 16,9 & 150 & 30,2 & 4 & 1,2 & 9 & 5,4 & 13 & 2,6 \\
\hline $\begin{array}{l}\text { Hemşireliğin sürekli gözde bir meslek olacağını düşündüğüm için } \\
\text { hemşireliği seçtim }\end{array}$ & 34 & 10,3 & 19 & 11,4 & 53 & 10,7 & 37 & 11,2 & 27 & 16,3 & 64 & 12,9 \\
\hline Hemşirelik insanların gözünde saygın bir meslektir & 51 & 15,4 & 25 & 15,1 & 76 & 15,3 & 21 & 6,3 & 16 & 9,6 & 37 & 7,4 \\
\hline Hemşirelikten başka seçim şansım yoktu & 25 & 7,6 & 18 & 10,8 & 43 & 8,7 & 101 & 30,5 & 49 & 29,5 & 150 & 30,2 \\
\hline Hemşirelikte işsiz kalınmayacağını düşünüyorum & 76 & 23,0 & 54 & 32,5 & 130 & 26,2 & 13 & 3,9 & 10 & 6,0 & 23 & 4,6 \\
\hline Hemşirelikte iyi para kazanilır & 36 & 10,9 & 21 & 12,7 & 57 & 11,5 & 20 & 6,0 & 7 & 4,2 & 27 & 5,4 \\
\hline Hemşirelik dışında yapabileceğim başka bir iş yok & 16 & 4,8 & 13 & 7,8 & 29 & 5,8 & 97 & 29,3 & 51 & 30,7 & 148 & 29,8 \\
\hline Hemşirelik alanında lider olabileceğimi düşünüyorum & 57 & 17,2 & 23 & 13,9 & 80 & 16,1 & 15 & 4,5 & 11 & 6,6 & 26 & 5,2 \\
\hline Hemşirelik ailem ve benim için uygun bir iştir & 0 & 0 & 1 & 0,6 & 1 & 0,2 & 9 & 2,7 & 14 & 8,4 & 23 & 4,6 \\
\hline $\begin{array}{l}\text { Hemşireliğin yarı zamanlı ve vardiyalı çalışma koşullarının olması } \\
\text { bana cazip gelmektedir }\end{array}$ & 41 & 12,4 & 29 & 17,5 & 70 & 14,1 & 51 & 15,4 & 16 & 9,6 & 67 & 13,5 \\
\hline $\begin{array}{l}\text { Gereksinimlerimi karşılayabilecek bir meslek aradım ve } \\
\text { hemşireliği seçtim }\end{array}$ & 58 & 17,5 & 28 & 16,9 & 86 & 17,3 & 33 & 10,0 & 12 & 7,2 & 45 & 9,1 \\
\hline
\end{tabular}


ise \%64,2'sinin ilk 10 tercihleri arasında yer aldığı bulunmuştur (19). Sağlık Meslek Lisesi öğrencilerinde yapılan çalışmada, öğrencilerin $\% 67,2$ 'sinin hemşireliği isteyerek ve \%64'ünün ilk sırada tercih ettikleri bulunmuştur (20). Bu sonuçlardan farklı olarak, bir çalışmada hemşireliği ilk 3 sırada tercih edenlerin oranı oldukça düşük bulunmuştur (21). Son yıllarda yapılan çalışmaların çoğunda hemşireliğin tercih nedenlerinin başında iş bulma olanağı gelmektedir $(7,9,10,20)$. Hemşireliğe olan gereksinim ve bunun paralelinde iş bulma olanağının diğer alanlara göre kolay olması mesleğin ilk sıralarda tercih edilmesini sağlamaktadır. Çalışmamızda öğrencilerin yarıdan fazlası hemşirelik bölümünü isteyerek seçtiklerini ifade etmiştir. Hemşirelik öğrencilerinin meslek seçiminin incelendiği faklı çalışmalarda da benzer sonuçlara ulaşılmıştır $(8,17,18,22-24)$. Çalışmamızda öğrencilerin çoğunluğunun hemşirelik bölümünden memnun olduğu, mesleği benimsedikleri ve bölüm değiştirmeyi düşünmedikleri sonucuna ulaşılmıştır. Hemşirelik öğrencilerinde yapılan farklı çalışmalarda da çoğunun bölüm değiştirmeyi düşünmeği $(1,7)$, mezun olduktan sonra hemşirelik mesleğinde kalmak istedikleri bulunmuştur (25). Sağlık Meslek Lisesi hemşirelik bölümü öğrencileri ile yapılan bir çalışmada öğrencilerin \%49'unun hemşireliği sevdikleri, \%68,4'ünün profesyonel bir meslek olarak gördükleri ve \%51'inin hemşirelikte lisans eğitimi almak istedikleri belirlenmiştir (20).

Çalışmamızda öğrencilerin mesleği benimseme durumu ile HMSÖ MU alt boyutu puan ortalaması arasında anlamIı fark saptanmıştır $(p=0,00)$. Çalışma bulgumuza benzer olarak İnce ve Khorshid'in çalışmasında da aynı sonuca ulaşıımıştır (7). Kalkım ve ark.'nın çalışmasında mesleğini isteyerek tercih eden öğrencilerin puan ortalaması $(60,22 \pm 17,98)$, mesleğini istemeyerek tercih edenlerin puan ortalamasından $(46,02 \pm 15,05)$ yüksek ve istatistiksel olarak anlamlı bulunmuştur (8). Hemşirelik öğrencilerinin meslek seçimini etkileyen faktörlerin incelendiği bir çalışmada Meslek Seçimi Ölçeği'nin "mesleki uygunluk" düzeyi ve "yaşamsal nedenler" alt ölçekleri yüksek bulunmuştur (5). Yapılan çalışmalarda hemşirelik öğrencilerinin mesleğini sevdikleri ve meslek yaşamlarını hemşire olarak sürdürmek istedikleri belirlenmiştir $(8,18,21,23)$. Hemşirelik mesleğinin öğrenciler tarafından sevilmesi, onların mesleği benimsedikleri ve hemşireliği kendilerine uygun buldukları gerçeğini ortaya koymaktadır. Yapılan birçok çalışmada hemşirelik öğrencilerinin meslekle ilgili gelecek planları yaptıkları, bölümlerini değiştirmek istemedikleri ve mezun olduktan sonra mesleğin uygulayıcısı olmak istedikleri sonucuna ulaşılmıştır $(7,10,18,22,23)$. Çalışmamızda bölüm değiştirmeyi düşünmeyen öğrencilerin $\mathrm{MU}$ puan ortalaması $(44,70 \pm 12,23)$, bölüm değiştirmeyi düşünen öğrencilerin puan ortalamasından $(35,11 \pm 12,70)$ yüksek ve istatistiksel olarak anlamlı bulunmuştur $(p=0,00)$. Yapılan farklı çalışmalarda da bölümünü değiştirmek istemeyen öğrencilerin MU puan ortalaması yüksek ve istatistiksel olarak anlamlı bulunmuştur $(7,25)$. Çalışmalardan elde edilen bulgular öğrencilerin hemşirelik mesleğini kendilerine uygun bulduklarını göstermektedir.

Çalışmamızda öğrencilerin Meslek Seçimi Ölçeği'ndeki sorulara göre meslek seçiminde etkili olan ilk üç neden her iki cinsiyette de sırasıyla; “Her zaman insanlara yardım etmek istemişimdir" (\%36,4)", "Çevremdeki insanlar iyi bir hemşire olacağımı söylerler $(\% 30,2)$ " ve "Kendimi ifade edebilmemi sağlayan bir iş yapmak istedim $(\% 27,6) "$ maddeleridir. Kalkım ve ark.'nın çalışmasında öğrencilerin meslek seçimindeki etkili olan maddeler çalışmamızdaki sıralama ile benzerlik gösterirken (8), diğer çalışmalarda meslek seçiminde etkili olan en önemli maddeler; "Hemşirelikte işsiz kalınmayacağını düşünüyorum”, "Her zaman insanlara yardım etmek istemişimdir", "Kendimi ifade edebilmemi sağlayan bir iş yapmak istedim", "Çevremdeki insanlar iyi bir hemşire olacağımı söylerler" şeklindedir $(7,17)$. Çalışmamızdan elde edilen bulgulardan özellikle insanlara yardım etme isteği, hemşireliğin bakım felsefesi ile de doğrudan uyuşmaktadır. Bu istek ile hemşirelik eğitimine başlayan ve eğitim sürecinde hemşirelik felsefesi ile yoğrulan öğrencilerin mesleğini icra ederken yaşadıkları doyum da daha yüksek olacaktır. İnsana yaklaşımı barındıran her meslekte olduğu gibi hemşireliğin de isteyerek yapılması verilen hemşirelik hizmetinin kalitesinin artmasında önemlidir.

\section{Sonuç ve öneriler}

Çalışmaya katılan öğrencilerin yarıdan fazlasının hemşirelik mesleğini isteyerek ve ilk sırada tercih ettikleri belirlenmiştir. Öğrencilerin okudukları bölümden memnun olmaları, mesleği benimsemeleri ve bölüm değiştirmeyi düşünmemeleri olumlu bir sonuçtur. Kız ve erkek öğrencilerde mesleki uygunluk oranları yüksek bulunmuştur. Öğrencilerin meslek seçiminde en önemli etken "Her zaman insanlara yardım etmek istemişimdir" ifadesi olmuştur. Meslek seçiminde etkisi olmayan madde ise "Hemşirelikten başka seçim şansım yoktu" ifadesidir. Bu sonuçlar doğrultusunda; üniversite sınavlarına hazırlanan öğrencilere hemşirelik mesleğini tanıtıcı programlar hazırlanması, hemşirelik bölümünde öğrenimini sürdüren öğrenciler için okul-hastane iş birliği ile kariyer planlama ve mesleğin statüsünü arttırmaya yönelik eğitim programlarının düzenlenmesi, mesleki çalışma koşullarının iyileştirilmesi ve toplumun mesleğe yönelik algısını olumlu yönde arttırmak için mesleki örgütlerle işbirliği içinde çalışılması önerilmektedir 


\section{Kaynaklar}

1. Erhan Şentürk S. Meslek olarak hemşirelik ve hemşirelikte etik ilkeler, İstanbul: Nobel Tıp Kitabevleri Ltd. Şti.; 2013. ss.1-7.

2. Kars V, Arslan N, Erik L, Avcı N, Bucaktepe PG, Celepkolu T, Şahin HA4. Lise son sınıf öğrencilerinin meslek seçiminde karşılaştığı sorunlar ve bu sorunların anksiyete ve depresyonla ilişkisi. Dicle Tıp Derg 2014;41:187-90. [CrossRef]

3. Deniz S. Bireyin meslek seçimini etkileyen kaynaklar: yeni teknolojilerden internet. Muğla Üniversitesi SBE Derg 2001;6:1-9. http://www.sobbiad.mu.edu.tr/index.php/asd/article/view/81/86

4. Gökdeniz I, Merdan E. Meslek seçimi ile il tatmini ilişkisi. Aksaray Üniversitesi İktisadi ve İdari Bilimler Fakültesi Derg 2016;8:111-21.

5. Ergün G, Güzel A. Sağlık Yüksekokulu Hemşirelik Bölümü ilk ve son sınıf öğrencilerinin meslek seçimini etkileyen faktörlerin incelenmesi. Int J Hum Sci 2010;13:1271-84. https://j-humansciences.com/ojs/ index.php/IJHS/article/view/3664/1711

6. IIlhan Erkal S, Yalçın AS, Sancar B. Ankara Üniversitesi Sağlık Bilimleri Fakültesi öğrencilerinin ebelik ve hemşirelik bölümlerini seçme nedenleri. Ankara Sağlık Bilimleri Derg 2012;73-90. https:// dergipark.org.tr/tr/download/article-file/509437

7. Ince $S$, Khorhsid L. Hemşirelik öğrencilerinin meslek seçimini etkileyen faktörlerin belirlenmesi. Anadolu Hemşirelik ve Sağlık Bilimleri Derg 2015;18:163-71. https://dergipark.org.tr/en/ download/article-file/29670

8. Kalkım A, Sağkal Midilli T, Uğurlu E, Gülcan E. Hemşirelik öğrencilerinin meslek seçimi ve etkileyen değişkenlerin incelenmesi. Uluslararası Hakemli Hemşirelik Araştırmaları Derg 2015;4:41-60.

9. Kızğut S, Ergöl ş. Sağlık Yüksekokulu öğrencilerinin hemşireliği algılayışı hemşirelik rollerine ve hemşireliğin geleceğine bakışı. Anadolu Hemşirelik ve Sağlık Bilimleri Derg 2011;14:10-5. https:// dergipark.org.tr/en/download/article-file/29498

10. Özpancar N, Aydın N, Akansel N. Hemşirelik birinci sınıf öğrencilerinin hemşirelik mesleği ile ilgili görüşlerinin belirlenmesi. Cumhuriyet Hemşirelik Derg 2008; 12:9-17. http://eskidergi.cumhuriyet.edu.tr/ makale/2325.pdf

11. Dal Ü, Arifoğlu $B C$, Sala Razı G. What factors influence students in their choice of nursing in North Cyprus? Procedia Soc Behav Sci 2009;1:1924-30. [CrossRef]

12. Wilkes $L$, Cowin $L$, Johnson $M$. The reasons students choose to undertake a nursing degree. Collegian 2015;22:259-265. [CrossRef]

13. Marcinowicz L, Owlasiuk A, Slusarska B, Zarzycka D, Pawlikowska $T$. Choice and perception of the nursing profession from the perspective of Polish nursing students: a focus group study. BMC Med Educ 2016;16:243. [CrossRef]
14. Velioğlu P. Hemşireliğin düşünsel temelleri. İstanbul: Alaş Ofset; 1994. ss.1-18.

15. Zysberg L, Berry D. Gender and students' vocational choices in entering the field of nursing. Nurs Outlook 2005;53:193-8. [CrossRef]

16. Önler E, Saraçoğlu GV. Hemşirelikte meslek seçimi ölçeğinin güvenilirlik ve geçerliliği. DEUHYOED 2010;3:78-85. https://pdfs. semanticscholar.org/a902/faf22f7f80f4b1cdf889305d31e3a50 0c216.pdf

17. Özdelikara A, Ağaçdiken S, Aydın E. Hemşirelik öğrencilerinin meslek seçimi ve etkileyen faktörler. ACU Sağlık Bil Derg 2016;:83-8. http:// www.acibadem.dergisi.org/uploads/pdf/pdf_AUD_347.pdf

18. Çınar Yücel Ş, Kocaçal Güler E, Eşer İ, Khorshıd L. İki farklı eğitim sistemi ile öğrenim gören hemşirelik son sınıf öğrencilerinin hemşirelik mesleğini algılama durumlarının karşılaştıııması. Ege Üniversitesi Hemşirelik Yüksek Okulu Derg 2011;27:1-8. https:// dergipark.org.tr/en/download/article-file/825492

19. Çıtak Tunç G, Akansel N, Özdemir A. Hemşirelik ve sağlık memurluğu öğrencilerinin meslek seçimlerini etkileyen faktörler. Maltepe Üniversitesi Hemşirelik Bilim ve Sanatı Derg 2010;3:24-31. http:// hemsirelik.maltepe.edu.tr/dergiler/cilt3sayi1/24-31.pdf

20. Dikeç G, Karakurt S, Bayram A, Zeybek B, Dağlı D. Sağlık meslek lisesi son sınıf öğrencilerinin hemşirelik mesleğine ilişkin düşünceleri. Sağlık ve Hemşirelik Yönetimi Derg 2017;3:127-35. [CrossRef]

21. Altuntaş $S$, Korkmaz Ş, Baykal Ü ve ark. Hemşire öğrencilerin kariyer yönelimleri ve bunu etkileyen faktörler. İstanbul Üniversitesi FNHYO Derg 2005;13:179-97. https://dergipark.org.tr/tr/download/ article-file/95359

22. Şirin A, Öztürk R, Bezci G, Çakar G, Çoban A. Hemşirelik öğrencilerinin meslek seçimi ve mesleği uygulamaya yönelik görüşleri. Dirim Tıp Gazetesi 2008;83:69-75.

23. Güdücü Tüfekci F, Yıldız A. Öğrencilerin hemşireliği tercih etme gerekçeleri ve gelecekleri ile ilgili görüşleri. Atatürk Üniversitesi Hemşirelik Yüksekokulu Derg 2009;12:31-7. https://dergipark.org.tr/ en/download/article-file/29445

24. Zencir G, Eşer İ. Hemşirelik öğrencilerinin hemşirelik mesleğine yönelik tutumları ile hemşirelik tercihi arasındaki ilişki: Türkiye örneği. DEUHFED 2016;9:30-7. https://dergipark.org.tr/tr/ download/article-file/753019

25. Altunkürek ŞZ, Gençbaş D, Çiçek H, Bebiş H, Özdemir S. Hemşirelik öğrencilerinin mesleği tercih etme durumları ile mesleki kariyer planları arasındaki ilişkisinin belirlenmesi. Cumhuriyet Hemşirelik Derg 2017;6:74-82. 